v. $13, n .5$

Vitória-ES, Sep.-Oct. 2016

p. $27-50$ ISSN 1808-2386

http://dx.doi.org/10.15728/bbr.2016.13.5.2

\title{
Impact of Changes in Accounting Standards in Debt Ratios of Firms:
}

Evidence in Brazil

\author{
André Aroldo Freitas de Moura ${ }^{\dagger}$ \\ University of Birmingham \\ Antônio Carlos Coelho ${ }^{\Omega}$ \\ Federal University of Ceará - UFC
}

\begin{abstract}
This research investigates the impact of changes in debt ratios of Brazilian firms due to the IFRS adoption. We make a comparison between the forecast of the time-series of debt ratios accounted until 2007 for the span from 2008 to the first quarter of 2015 with those effectively accounted from 2008 to the first quarter of 2015 derived from the new accounting standard. The research utilizes SARIMAX model and Chow's (1960) structural break forecast test, controlling for changes originating from the macroeconomic environment as well. We find evidence of significant changes in the debt ratio towards both higher and lower debt with predominance of greater ratios. This result is consistent with past literature in Europe, Australia and New Zealand. Nevertheless, we do not find evidence of a structural break in the Financial Dependency ratio. Moreover, there is no evidence of any distinct effects across different industries. The research provides new evidence confirming the informational effects of IFRS by utilizing a robust time-series model with macroeconomic controls in an innovative approach towards the accounting environment.
\end{abstract}

Keywords: Projection of debt ratios. Convergence to IFRS. Time series. Brazil.

\footnotetext{
*Author for correspondence:

$\dagger$. PhD candidate in Accounting and Finance

Link: University of Birmingham - UK

Address: Apt 41, 29 longleat avenue. B15 2DF. Birmingham.

West-midlands. U.K.

E-mail: andrearoldo2@hotmail.com

afm410@student.bham.ac.uk
}

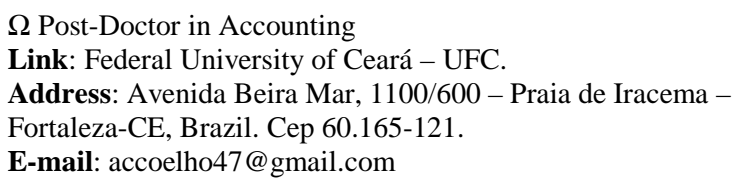

Fortaleza-CE, Brazil. Cep 60.165-121. 


\section{INTRODUCTION}

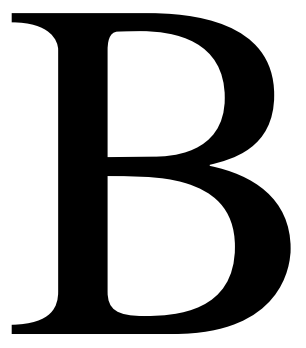

razil has recently undergone a transition in its accounting system. In order to reach this transition, the Committee of Accounting Pronouncements (Comitê de Pronunciamentos Contábeis - CPC) issued between 2007 and 2014, 48 technical pronouncements, 20 interpretations and 8 guidelines that aims to converge the Brazilian accounting standards to the international standards. Some of these were introduced in the first phase of convergence that occurred in 2008. The period between 2008 and 2009 represents the partial convergence to IFRS whereas the second phase of the convergence was completed in 2010, which is the moment of full convergence to the International Financial Reporting Standards (IFRS).

The new Brazilian accounting standard is expected to provide higher predictive capacity to accounting information (ERNST \&YOUNG TERCO, 2011). In this sense, we argue that the forecasting ability of accounting is not necessarily achieved only by the adoption of accounting principles technically more demanding and market-oriented, but also by aspects associated with the preparation and disclosure of information.

Aspects that may affect the information quality of accounting and, as a consequence, its forecasting ability may be related to the level of ownership concentration, the effective enforcement of regulatory bodies, differences between accounting standards, investor protection mechanisms, corporate governance structure and earnings management (ALFORD ET AL., 1993; ALI; HWANG, 2000; SCHIPPER; VINCENT, 2003; SILVA, 2013).

Since the change of the accounting standard, we expect that the representation of the economic and financial situation of the company has changed. Furthermore, we predict a change in the quality of information reported, as the international standard has superior quality with respect to information for decision-making of external users (BARTH; LANDSMAN; LANG, 2008; ERNST \&YOUNG TERCO, 2011).

Previous research investigated this topic only during the period of partial adoption of IFRS concerning the quality of accounting information and the behavior of economic and financial indicators. The majority of these Brazilian studies focus on the investigation of the subject in the period of the partial mandatory adoption of IFRS (PEREIRA ET AL.,2006; LEMES; SILVA, 2007; KLANN; BEUREN; HEIN, 2009; LEMES; CARVALHO, 2009; BARBOSA NETO; DIAS; PINHEIRO, 2009; LIMA, 2010; MARTINS, PAULO (2010); CARVALHO ET AL., 2011; LIMA, 2011). Regarding this phase, there are few studies that 
investigate the behavior of financial ratios (positive or negative) and other accounting aggregates according to the intensity that the convergence affected accounting numbers and financial ratios used by external users, as it is the case of performance measures (LANTTO; SAHLSTRÖM, 2009; MARTINS; PAULO, 2010). This fact is due to the following two factors. Firstly, few companies published financial statements under IFRS or Brazilian General Accepted Accounting Principles (BRGAAP) standards, which hindered the process of comparison between the results in the two standards. Secondly, the adoption of international standards coincided with the strong macroeconomic instability period due to the 2008 financial crisis, which would affect the economic and financial situation of firms. There is still a gap in the literature in this area, in particular, concerning the impact of the full IFRS adoption (implemented in 2010) on economic and financial ratios.

It is worth noting that Lemes and Silva (2007) discuss that differences in the adoption of international standards in Brazil are more pronounced in companies from certain type of industries, which are subject of specific regulation. We highlight the following examples: (i) telecommunications companies, which are regulated by the National Telecommunications Agency (ANATEL); (ii) electric companies, which are regulated by the National Electric Energy Agency (ANEEL); and (iii) financial and insurance companies, which are regulated respectively by the Central Bank of Brazil (BCB) and the Superintendency of Private Insurance (SUSEP). These authors report that there regulatory bodies tended to edit specific resolutions and sectorial standards in order to regulate their accounting operations.

Considering the accounting transition and the differences between the international and the Brazilian standard (in force until 2007) (CARVALHO ET AL., 2011), we argue that the decision-making process of the firm, based on financial indicators, may have been affected, as these indicators may have been altered due to the convergence. Changes in the accounting treatment of financial leasing, and in the recognition of exchange and conversion rates may have caused impacts on debt ratios. Thus, considering that the event may have altered the temporal behavior of such ratios, analysts' forecasts based on the long-term behavior of timeseries of debt ratios would suffer bias if we do not recognize the impact of the event on the referred time-series ratios.

The main aim of this research is to investigate to what extent debt ratios based on accounting information may change due to events arising from changes in current accounting standard. Moreover, we investigate the impacts of the new standard according to different industries, considering their specific operational characteristics. 
By considering the change provided expressly by the CPCs 06, 11, 12, 27 and 28, propose various schemes for the recognition and measurement of items used for the calculation of debt ratios, we formulated the hypothesis that debt ratios based on accounting information were affected significantly from changes in the Brazilian accounting standard.

Such conjecture considers that the international standard, by definition, favors substance over form, and would therefore provide greater reliability and predictive capacity of accounting numbers (BARTH; LANDSMAN; LANG, 2008; LANTTO; SAHLSTRÖM, 2009), differentiating in time the composition of debt ratio.

In the context of accounting standard changes, empirical research on the consequences of its adoption are strongly focused on countries of the European Union (CALLAO; JARNE; LAÍNES, 2007; COSTA, 2008; SILVA; COUTO; CORDEIRO, 2009; LANTTO; SAHLSTRÖM, 2009; CALIXTO, 2010; CORDAZZO, 2008; SILVA; NAKAO, 2011).

In addition, there is a discussion about the informational benefits and economic costs for the adoption of IFRS in Brazil. In this sense, the costs incurred in the adoption process were very high. However, there is no empirical evidence on a large scale certifying the benefits of this adoption for Brazilian companies or its stakeholders. It is still not clear for the academia the relation about the cost-benefit of the convergence to IFRS. This research sheds light that there is evidence that the full adoption of IFRS presented a different informational result arising from the accounting practice. We interpret this finding as an informational benefit, since it took place due to effective accounting changes per se.

The proposed method consists of modeling the time-series of the financial ratios, by testing whether the event of the change in accounting standards causes structural breaks in the random walk of the debt ratios; this test (CHOW, 1960) compares the forecasted series with the actual observed series from the defined event. In order to model the time-series, we also include macroeconomic variables, accepting the fact that the economic and financial situation of the company can be effectively changed, and not its accounting expression. That is, macroeconomic changes may have affected the businesses of firms; thus, we attempt to control this effect with the use of macroeconomic variables.

\section{LITERATURE REVIEW}

\subsection{CHARACTERISTICS OF ACCOUNTING INFORMATION}

The vision of the usefulness of accounting as an information system that meets the interest of various groups associated with the company, as well as for contractors around the 
company, depends on how it provides information to these agents (COELHO; LIMA 2009). Considering the multiple demand and the diverse utility of accounting information for those interested it, the predicates of the information disclosed in the financial statements by companies depend on characteristics, which depict the various needs of users. Thus, the quality of the accounting information will depend on the use that is made of it, since users have different interests and therefore, a different view on the information characteristic of the same accounting information. In addition, the quality of accounting information depends on the context in which it is being used (SCHIPPER; VINCENT, 2003).

Coelho and Lima (2009) state that references to the issue of the quality of accounting numbers will report to economic constructs that represents the wealth of the company, illustrated by the Net Equity (NE), and to the flow of revenue marginally produced by the company (the earnings).

Considering the difficulty of operationalizing the concept of the quality of accounting information and its various interpretations Schipper and Vincent (2003) argue that the quality of accounting earnings is related to the analysis of its usefulness for users. The authors based their view of the utility approach according to its usefulness for decision-making process. The Financial Accounting Standards Board (FASB) describes this issue in their Statement of Financial Accounting Concepts No. 1 (SFAC 1), which states that the purpose of financial statements is to provide useful information for business economic decisions and this is the most important criterion to judge accounting choices. Furthermore, the idea of usefulness of accounting information can be treated empirically and is commonly used in accounting research.

Schipper and Vincent (2003) define the quality of accounting earnings as the extent to which reported earnings faithfully represent the economic event that it intends to measure. This definition is based on the Hicksian income model, which can be characterized as an economical concept that effectively remunerates the owners of capital assuring the company's continuity, and on SFAC 2 (FASB, 1980).

Schipper and Vincent (2003) then provide several ways to define the quality of earnings and its links with empirical measurements:

a) Ideas arising from attributes of earnings time series;

b) Characteristics derived from principles and accounting standards, basically focused on the usefulness of the information; 
c) Relationship between operating earnings, operating cash flows and adjustments arising from the accrual basis; and

d) Consequence of decisions adopted in earnings calculation derived from economic incentives or technical capacity of accountants and auditors.

One of the topics related to the subject discusses the focus of information comparability, which is the quality of information that enables users to identify similarities and differences between two sets of economic phenomena (FASB, 1980; IASB, 2010). FASB (1980) argues that a greater comparability of accounting information can be set as a goal, but this will not be achieved by doing different things seem alike, more than doing similar things seem different. According to Choi, Frost and Meek (1999), the information is comparable, if it is similar enough so that users can compare the information without having specific knowledge of more than one accounting system. Thus, information disclosed by companies may be more useful if the comparison among companies by investors and other stakeholders is less costly (LIMA, 2011). The more comparable corporate disclosures facilitate the differentiation between the more and the less profitable companies, and between those of higher or lower risk, which results in reducing the information asymmetry component among investors. These attributes resulting from greater comparability can also increase market liquidity and reduce the cost of capital of companies (LIMA, 2011). Increased comparability of financial statements among companies from different countries could facilitate investments across borders and the integration of capital markets; recent evidence supports these predictions (AGGARWAL; KLAPPER; WYSOCKI, 2005; LEUZ; TRIANTIS; WANG, 2008). A greater comparability can also have an impact on corporate decisions. Therefore, financial statements that are more comparable enable users interested in the accounting information to make better investment choices due to the greater knowledge of market companies. In addition, companies with comparable financial statements can increase the efficiency in the relationship with suppliers and customers in other countries (LIMA, 2011). It can also allow the transaction with governments of other countries (HAIL; LEUZ; WYSOCKI, 2009). In summary, the way to visualize the quality of information of earnings will depend on the approach, the measurement of earnings, the degree of adequacy to accounting standards or the usefulness of information to various users (COELHO; LIMA, 2009).

Regarding the emphasis of accounting quality, several changes originated from the process of convergence to international standards changed the financial position of companies. We can cite, in particular, changes in the recognition of financial leasing and the 
effects of changes in the use of exchange and conversion rates upon the financial statements. These may have caused an increase in debt ratios of leasing firms and companies in general (CARVALHO et al, 2011).

As mentioned in CPC 06, about the changes in the accounting treatment for leasing operations, the leased asset of the company which does leasing operations should be classified as fixed assets at the present value of the minimum capital lease installments adjusted by the accumulated depreciation. Moreover, the obligation of its payment must be accounted as a liability at the present value of outstanding installments. In practice, prior to such adjustment, the records of financial leasing operations were not presented with due transparency, as the events of operational leasing were being registered as financial leasing by companies. Therefore, there has been an increase on the transparency and the information quality since the adoption of the new Brazilian accounting standards. In addition, CPC 12 proposed that long-term and relevant short-term assets and liabilities must be recorded at present value on the closing date of the asset position, using contractual or implicit rate, which tends to cause changes in the businesses' current assets. Furthermore, according to the CPC 08, transaction costs are now recorded in a fundraising allowance account (liabilities or net equity), and issued debt securities are now recorded at the net value of the transaction; thus, they began to be recognized in income on the accrual basis (CARVALHO et al, 2011). Therefore, the comparability of accounting information on debt may have been affected, which now could report evidence of changes in debt ratios derived from the accounting standard change.

\subsection{DEBT RATIOS AND ACCOUNTING STANDARDS}

Research in different countries show that the convergence of international standards has occurred gradually and substantially, varying according to the form of local norms (HUNG; SUBRAMANYAM, 2007; CALLAO; JARNE; LAÍNEZ, 2007; COSTA, 2008; LANTTO; SAHLSTRÖM, 2009; TSALAVOUTAS; EVANS, 2010). Generally speaking, they investigate informational changes regarding the comparability of financial statements, strategic changes in the decision-making process and impact of the accounting change for the capital market.

In Brazil, studies investigate differences originated from the financial statements, by making comparisons between the accounting standards of BRGAAP (revoked standards) and IFRS (CARVALHO; LEMES, 2002; LEMES; SILVA, 2007; PEREIRA ET AL, 2006; KLANN; BEUREN; HEIN, 2009; BARBOSA NETO; DIAS; PINHEIRO, 2009; MARTINS; PAULO, 2010; SILVA ET AL, 2011; CARVALHO ET AL, 2011; DANI; VESCO; 
BEZERRA, 2012; MARIA JÚNIOR ET AL, 2012; RIBEIRO ET AL, 2012). Such studies point as the originators of significant accounting differences the following accounting items: Equity Method (EM); Operating Earnings, Net Income and Net Equity, by the residual of several mutations; Goodwill; Derivatives; Deferred Assets; and Leasing.

Regarding the impact of the new accounting standard event in debt ratios, research is inconclusive, as the following studies indicate differences in debt ratios: (PEREIRA ET AL, 2006; MARTINS; PAULO, 2010; SILVA ET AL, 2011; CARVALHO ET AL, 2011; MARIA JÚNIOR ET AL, 2012; RIBEIRO ET AL, 2012). However, the studies of Klann, Beuren and Hein (2009), Barbosa Neto, Dias and Pinheiro (2009), and Dani, Vesco and Bezerra (2012) do not identify divergences among these financial ratios.

Divergences could both have emerged due to the use of methods, and due to various databases and distinct financial ratios as well as for not introducing macroeconomic control variables that would mitigate the effect of the macroeconomic environment, whose most visible example would be the 2008 financial crisis. Given the macroeconomic volatility driven by this crisis, such fact could not be neglected under the penalty of leading to bias inferences, which are not from the effective change in the borrowing process itself and not from the adoption of the new accounting standard.

In Europe, there is evidence of a significant change in debt ratios towards an increase in ratios and in the value of liabilities (LANTTO; SAHLSTRÖM, 2009: COSTA, 2008; LUEG; PUNDA; BURKERT, 2014). Similar evidence was found in New Zealand and Australia (STENT; BRADBURY; HOOKS, 2010; GOODWIN ET AL., 2008).

\section{RESEARCH DESIGN}

The data of this research was retrieved from the Economática ${ }^{\circledR}$ database, the Reference Form, Annual Information Form and the Standardized Financial Statements available on the institutional portals of the Brazilian stock exchange (BM\&FBovespa) and the Brazilian Security Exchange Commission (CVM). It is worth noting that we collected information from the consolidated financial statements.

The target population of this research are Brazilian publicly held equity companies based on the period from 1995 to the first quarter of 2015, which included 446 active firms. In order to reach the sample of this research, we applied the following filters:

1. To have sufficient data in order to calculate the variables; 
2. To have continuous data between 1995 and the first quarter of 2015 (20 years and 1 quarter or 81 quarters);

3. Not being a company from the financial sector, given the different regulations that they had for the change in accounting standards.

Only 75 companies remained in the sample after this filtering, highlighting that the most effective selection for the removal of observations referred to the availability of continuous quarterly data. We decided to include two more companies that had data available until the third quarter of 2014 and one until the fourth quarter of 2014, totalizing 78 sampled companies.

Even by considering the mandatory disclosure of basic accounting reports and using the CVM database, there is no explanation for such gaps, except for inadequate enforcement of the regulatory body and even from the market in requiring the disclosure and maintenance of such data in official accounting information databases. Brown, Preiato and Tarca (2014), for example, built an enforcement index for various countries in which Brazil is in a position far below than developed countries. In addition, Santos et al. (2014) find that the degree of compliance is very low in Brazil. We also choose to not seek another source for data (companies' website, for example) in order to maintain the integrity and the consistency of the data.

We analyzed two debt ratios, in the form defined by Assaf Neto (2010), using the following terminology:

1) $\operatorname{Debt}=[($ Current Liabilities + Long-term Liabilities $) /$ Net Equity $]$;

2) Financial Dependency $=[($ Current Liabilities + Long-term Liabilities $) /$ Total Assets].

We highlight that the financial liabilities were estimated using the methodology as proposed by Fleuriet, Kehdy and Blanc (2003).

Since the accounting standard change event lead to alterations in the economic and financial representation of the firm's debt, the empirical analysis is based on the comparison of historical values (before the change of the accounting method) estimated for the period subsequent to the implementation with the observed values, which were already impacted by the new accounting standard. 
When projecting what would have happened and by comparing to what effectively happened after the change, we come to a precise econometric estimation of the change, making the data comparable between themselves, from the point of view of intrinsic factors to the behavior of indicators - among these, economic factors, although they are exogenous to the 'accounting method' factor.

We highlight the limitation of all econometric method that uses projections, since the projection does not capture future occurrences of the structural breaks. Moreover, we do not expect any other event that may cause changes in the temporal future path of the variable under study beyond what was considered in this research.

When comparing the economic and financial situation of two distinct periods, we can come across with unobservable variations of macroeconomic aspects, which have not resulted from the simple change in the way of calculating debt ratios.

Additionally, we control possible effects from the economy, in order to isolate only the effect of the accounting change in debt ratios, with macroeconomic control variables, which are:

- Interest rate, estimated by the quarterly Selic rate;

- Gross domestic product (GDP) variation, measured by the natural logarithm of the GDP for the current quarter minus the natural logarithm of GDP in the previous quarter;

- Exchange rate variation, calculated based on the natural logarithm of the dollar exchange rate for the current month minus the natural logarithm of the dollar rate of the previous month (quarterly variation calculated based on the monthly exchange time series disclosed by the $\mathrm{BCB}$ );

- Ibovespa (Brazilian stock exchange index) variation, obtained by the natural logarithm of the Ibovespa's current quarter divided by the natural logarithm of the Ibovespa's previous quarter.

The tests were carried out by estimating coefficients through time-series analysis. Such tests aim to evaluate the occurrence of structural breaks in the series behavior of financial indicators in the fourth quarter of 2008 - as highlighted by Santos and Calixto (2010), the effects of the partial IFRS implementation would be noticeable only in the statements from the fourth quarter of 2008 - and in the fourth quarter of 2010. 
We used linear and homoscedastic models: SARIMA (Seasonal autoregressive integrated moving average) or SARMA (Seasonal autoregressive moving average), with seasonality being tested (both in autoregressive and moving average components) on every four quarters in the modeling and projection of the variables of interest.

When we detected the structural break in at least one of the aforesaid dates, we included macroeconomic variables in the model in order to control changes of the financial ratios resulting from effective economic change - for example, likely effects of the financial crisis of 2008 - with the use of the SARIMAX (Seasonal autoregressive integrated moving average with exogenous factors) model, by inserting the exogenous variables into the estimation of debt ratios.

The debt ratio was measured by the time series of each company; the Financial Dependency ratio was considered by the time series of the mean of the group of companies. The idea is to test the individual effect (firm to firm) and the average effect on the environment considered.

We also evaluate the behavior of the two ratios (Debt and Financial Dependency) across different types of industries, which are defined according to an adapted classification of the BM\&FBovespa into five groups: a) Industrial Goods, Basic Materials and Oil \& Gas; b) Cyclical and Non-Cyclical Consumption c) Construction and Transportation; d) Technology and Telecommunications; e) Public Utility. Segregation in only five groups was due to the reduced number of companies in the sample. This sectorial analysis met the same logic of the analysis of the total sample, by taking each company individually, and analyzing the frequency of companies with structural break as the analysis of Debt and the structural break behavior for the industry average as for the examination of Financial Dependency.

The econometric method of time series modeling and forecasting is the integrated autoregressive process of moving averages denoted SARIMAX $(p, d, q)(\mathrm{P}, \mathrm{D}, \mathrm{Q})$ displayed in formula 1, where $\mathrm{P}$ represents the autoregressive order of seasonality, $\mathrm{D}$ represents the number of differentiations required to achieve the modeling of seasonality, and Q represents the order of moving averages of seasonality. For each variable regressed, adopted the specification $(p, d, q)$, and seasonality $(\mathrm{P}, \mathrm{Q})$ respectively represented by $\phi_{1}$ and $\phi_{2}$, recommended by the appropriate tests during the modeling:

$$
\begin{aligned}
& W_{t}^{d}=\alpha_{1} W_{t-1}+\ldots+\alpha_{p} W_{t-p}+\varepsilon_{t}+\beta_{1} \varepsilon_{t-1}+\ldots+\beta_{q} \varepsilon_{t-q}+\phi_{1}+\phi_{2}+ \\
& \theta_{1} T X_{t}+\theta_{2} P I B_{t}+\theta_{3} C A M B_{t}+\theta_{4} I B O V_{t}
\end{aligned}
$$


Where:

$W_{t}^{d}:$ is the measure of the debt ratio in period $(t)$, given the number of lags $(d) ; W_{t-p}:$ is the measure of the debt ratio in the period in relation to the autoregressive order $(p) ; \beta_{1 \ldots q}$ : are the coefficients of the error due to the order of moving averages $(q) ; \varepsilon_{t}$ : is the error of the model; $\phi_{1}$ : is the regressive seasonality term; $\phi_{2}$ : is the moving average seasonality term; $\theta_{1.4}:$ are the coefficients of macroeconomic variables; $\varepsilon_{1 . . q}$ : is the error in relation to the order of moving averages $(q) ; p$ : is the autoregressive order; $q$ : is the moving average order; $T X_{t}=$ Interest rate in period $\mathrm{t} ; P I B_{t}=\mathrm{GDP}$ variation in period $\mathrm{t} ; C A M B_{t}=$ Exchange Rate Variation in period $\mathrm{t} ; I B O V_{t}=$ Variation of the Ibovespa in period $\mathrm{t}$.

At the stage of modeling the time series, we follow the methodology proposed by Box and Jenkins (1976) in which the econometric assumptions are tested through the following tests. The unit root test of Kwiatkowski-Phillips-Schmidt-Shin (KPSS); the information criterion of Schwarz (1978) for choosing the most parsimonious model; and the Lagrange Multiplier (LM) test of serial autocorrelation from Breusch-Godfrey with two and five lags. We also analyze the functions of serial autocorrelation and partial autocorrelation in conjunction with the Schwarz information criterion in order to choose the number of lags.

After choosing the most suitable model for the treatment of the time series, we applied Chow's (1960) forecasting structural break test in focused events (implementation of the new accounting standard), via the following procedures:

- We forecast the time series modeled from 1995 to the third quarter of 2008 (BRGAAP standard) for the quarters included between the fourth quarter of 2008 and the first quarter of 2015 ;

- To evaluate the event of the partial implementation of IFRS, we compare the sum of the Squared Quadratic Residues (SQR) of the estimated series with that from the observed series' coefficients through the structural break test between two specified trajectories, considering the fourth quarter of 2008 as the breaking point;

- Analogously, we forecast the modeled time series from 1995 to the third quarter of 2010 for the quarters between the fourth quarter of 2010 and the first quarter of 2015; 
- To examine the event of the full implementation of IFRS, we compare in a similar way, the SQR of the projected series with the SQR of the observed series, performing the structural break test in the $4^{\text {th }}$ quarter of 2010.

Following this approach, we identify whether different behaviors had occurred between the estimated and observed series considering the chosen event, as well as the trend of growth or decline observed in relation to the expected debt ratio, if the original trend of the historical series had been maintained.

In addition, the analyses are presented by segmenting the companies with unsecured liabilities (14) during the studied period, since the extreme financial situation of these companies can affect, regardless of accounting changes, the behavior of their debt ratios.

The reported results are the summary of processed ones - E-Views - not displaying details of the modeling of time series, as values for serial autocorrelation tests and Chow's (1960) test. It is noteworthy, moreover, that the method used has limitations with very volatile series, it is also worth mentioning that the temporal history of some companies' debt could not be modeled, i.e., the observed behavior of the debt ratios up until the cutoff date did not present significance in tests of assumptions for the econometric processing of time series.

\section{RESULTS}

The behavior of debt ratios show evidence of significant changes in the economic and financial representation of these measures; however, we do not find the same evidence for Financial Dependency measures.

\subsection{DEBT RATIO}

Table 1 illustrates the frequency of structural breaks in the behavior of the debt ratio in the sample companies, clearly expressing that approximately $60 \%$ of them had the expression of debt changed, both for the partial adoption as for the full adoption of the new accounting standard.

Table 1 - Debt Ratio - Structural Break in Temporal Behavior

\begin{tabular}{c|c|c|c|c}
\hline \multirow{2}{*}{ Structural Break } & \multicolumn{2}{|c|}{ 4th Quarter 2008 } & \multicolumn{2}{c}{ 4th Quarter 2010 } \\
\cline { 2 - 5 } & Quantity & $\%$ & $\underline{\mathbf{1 3}}$ & 17 \\
\hline No & $\underline{\mathbf{1 5}}$ & 19 & $\underline{\mathbf{5 6}}$ & 71 \\
\hline Yes & $\underline{\mathbf{5 4}}$ & 69 & 12 & 15 \\
\hline With a decrease in ratio & 23 & 30 & 44 & 56 \\
\hline With an increase in ratio & 31 & 40 & $\underline{\mathbf{9}}$ & 12 \\
\hline No Modeling & $\underline{\mathbf{9}}$ & 12 & $\underline{\mathbf{7 8}}$ & 100 \\
\hline Total & $\underline{\mathbf{7 8}}$ & 100 & & \\
\hline
\end{tabular}


According to the analysis, at least $69 \%$ of companies had structural break in the investigated period; on the other hand, at least $17 \%$ showed no change. The analysis of 9 companies remains impaired, as their debt ratios series could not be modeled, as even after the second differentiation their time series continued non-stationary.

Considering only the companies that could be modeled (69), the analysis shows that at least $78 \%$ had structural break in both focused moments. In addition, macroeconomic control variables proved to be effective, since by controlling the effect of structural breaks originated from economic volatility, another five companies showed no structural break. Therefore, without the inclusion of these variables, at least $85 \%$ of the actual number of companies (69) would show significant structural break in the chosen events.

Even by withdrawing the 14 companies that had unsecured liabilities at some point in the analyzed period (thirteen with structural break in the sense of decreasing the ratio in both periods, and one that was not possible to model), the remaining sample of 64 companies shows similar behavior to the full sample.

Among the companies that had structural breaks, 23 (in the first event) and 12 (in the second event) had their debt ratio reduced; the other companies (31 in the first event and 44 in the second event) reported an increase in its debt in relation to Net Equity.

Similar behavior was reported in research in Finland, the U.K., Australia and New Zealand, where there was a predominance of increase in the ratio (LANTTO; SAHLSTRÖM, 2009; LUEG; PUNDA; BURKERT, 2014; GOODWIN ET AL., 2008; STENT; BRADBURY; HOOKS, 2010), highlighting that the studies use descriptive statistics to report increases in ratios.

From the point of view of debt ratios series with a positive inclination, we speculate that such behavior would have its origin in the change of the accounting for financial leasing, as highlighted by Gallon et al. (2012) in a correlated study; as for those that had their ratio reduced, probably such preponderantly debt ratios were affected by changes in the amount of $\mathrm{NE}$ (denominator of ratio under review), as this aggregate was affected by the number of changes adopted in the new accounting standard.

Such an inference arises from not identifying evidence from other relevant accounting changes regarding debt items. Analytical and qualitative research evaluating factors originators of changes in the indicators over time are suggested to deepen and clarify such details. 
The analysis by industry, considering the 5 sectors defined earlier, on the evolution of the debt ratio (Table 2) also follows a detection of the frequency of the number of companies with the presence of structural break. We note that all sectors have a predominance of companies with structural breaks, repeating the distribution identified in the full sample. We highlight that the analysis considering the withdrawal of companies with negative equity caused no change in the ascertained inferences.

Therefore, we did not identify a distinguished sectorial behavior. However, we can indicate additional research, of analytical character, investigating sectorial differences in the form of debt.

Table 2 - Debt Ratio - Sectorial Frequency

\begin{tabular}{l|c|c|c|c|c|c}
\hline \multirow{2}{*}{ Sectors } & \multicolumn{3}{|c|}{ 4th Quarter 2008 } & \multicolumn{3}{c}{ 4th Quarter 2010 } \\
\cline { 2 - 8 } & Yes & No & No modeling & Yes & No & No modeling \\
\hline $\begin{array}{l}\text { Industrial Goods, Basic Materials and } \\
\text { Petrol \& Gas }\end{array}$ & 22 & 7 & 5 & 22 & 7 & 5 \\
\hline Cyclical and Non-Cyclical Consumption & 19 & 4 & 3 & 21 & 2 & 3 \\
\hline Construction and Transport & 3 & 1 & 0 & 3 & 1 & 0 \\
\hline Technology and Telecommunications & 2 & 1 & 0 & 2 & 1 & 0 \\
\hline Public Utility Total & 8 & 2 & 1 & 8 & 2 & 1 \\
\hline
\end{tabular}

All companies from the sectors Construction and Transportation; Public Utility; and Technology and Telecommunications presented an increase in the debt ratio both in the partial implementation of IFRS as in its final situation. The 12 companies that experienced a reduction in this ratio are located in the sector of Industrial Goods, Basic Materials and Petrol $\&$ Gas and in the activity of Cyclical and Non-Cyclical Consumption. The others are distributed amongst all sectors.

From the above, we can infer that the evidence leads to not rejecting the hypothesis that the introduction of the new Brazilian accounting standards affected the expression of Debt ratio from a set of Brazilian companies. An identical inference appears in Ribeiro et al (2012), Carvalho et al (2011) and Silva et al (2009). In contrast, our findings differ from the study by Barbosa Neto, Dias and Pinheiro (2009).

We present in Table 3 an illustrative example of the econometric processing test applied by taking the debt ratio series that showed the two behaviors identified in companies chosen at random. The behavior of the temporal path of the companies selected at random is reproduced in figures 1 and 2 . 
Table 3 - The Modeling of Time Series of the Debt Ratio

\begin{tabular}{|c|c|c|c|c|c|c|c|c|c|c|}
\hline COMPANY & $\mathbf{R}^{2}$ & D & $\mathbf{A}$ & $\mathbf{M}$ & $\mathbf{V}$ & ST & $\mathbf{A S}(2)$ & $\mathbf{A S}(5)$ & $\begin{array}{c}\text { CHOW } \\
2008\end{array}$ & $\begin{array}{c}\text { CHOW } \\
2010\end{array}$ \\
\hline \multirow{2}{*}{$\begin{array}{c}\text { AMPLAENER } \\
\text { G } \\
\text { (with break) }\end{array}$} & 0.75 & 0 & 1996Q3 & $\mathrm{AR}(1)$ & $\begin{array}{l}\text { GDP, } \\
\text { S.VC, }\end{array}$ & $\mathrm{F}$ & 0.35 & 0.23 & $0 * * *$ & $0 * * *$ \\
\hline & & & 2015Q1 & & I & $x^{2}$ & 0.32 & 0.19 & $0 * * *$ & $0 * * *$ \\
\hline BRASMOTOR & 0.72 & 1 & 1997Q2 & $\mathrm{MA}(1), \mathrm{MA}(4)$ & & $\mathrm{F}$ & 0.48 & 0.12 & 1 & 1 \\
\hline (without break) & & & 2015Q1 & & & $x^{2}$ & 0.46 & 0.11 & 1 & 1 \\
\hline
\end{tabular}

where: *** Significant at the 1\% level; D: Number of differentiations of the model; A: Sample; M: Modeling; V: Macroeconomic variables; ST: Statistics; F: F Test; $x^{2}$ : Chi-square test; GDP: GDP growth rate; S: Interest rate (SELIC); VC: Exchange growth rate; I: Ibovespa's growth rate; C: Intercept; AR: Autoregressive term; MA: Moving average term; SAR: Autoregressive seasonality term; SMA: Moving average term; AS (2): Serial autocorrelation with two lags; AS (5): Serial autocorrelation with five lags; Chow2008: Structural Break in the fourth quarter of 2008; Chow2010: Structural Break in the fourth quarter of 2010. We highlight that the complete data of all series are available with the authors.

Note that the projected lines reflect the existing behavior up until the moment of the analyzed events; in viewing the behavior of the observed index pertaining to AMPLAENERG (whose test indicated behavior break), the path of the observed series has a positive inclination, which causes the residue, statistically significant, to present a positive behavior. In case of the debt ratio for BRASMOTOR (whose test indicated no structural break), the residue behavior between observed and projected data proved to be invariant and does not indicate statistical significance.
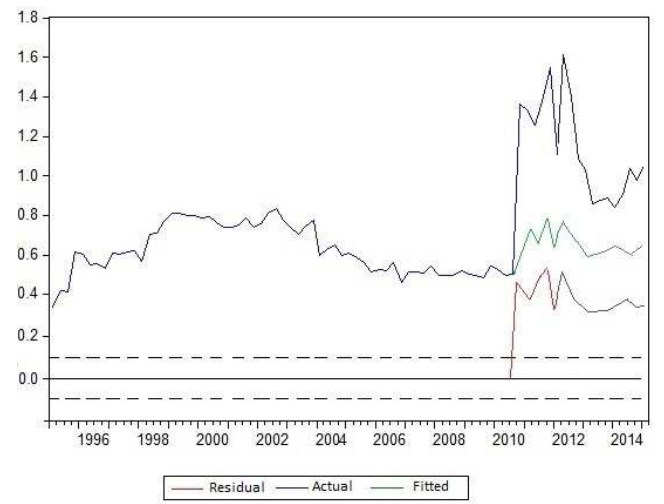

Figure 1 - AMPLAENERG

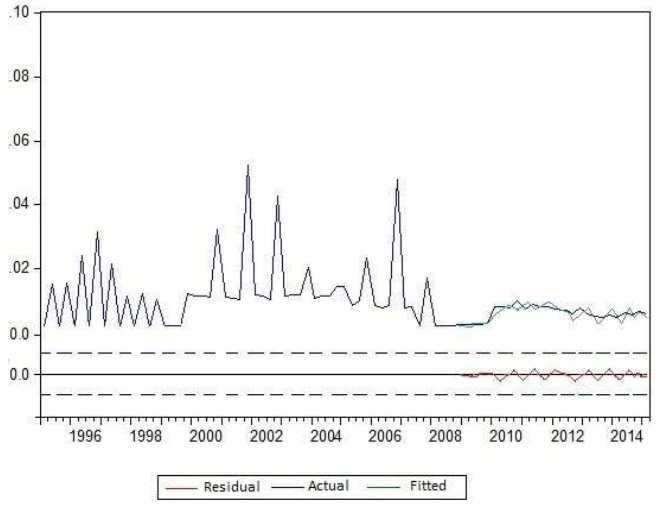

Figure 2 - BRASMOTOR

\subsection{FINANCIAL DEPENDENCY RATIO}

The behavior of financial dependency ratios did not appear in the group of companies with significant structural break. The time series used for the test was based on the average indicator of financial Dependency ratio of the 75 companies and it was unable to be modeled by SARIMAX. Even by processing a more homogeneous series, with the average calculated for 63 companies, and after withdrawing 12 very volatile series that presented outliers (values 
that differed the equivalent of five standard deviations) in its long-term behavior, we do not identify a structural break signal in their behavior (Table 4). We highlight that the same result was found when three companies were included that had data available up until the third quarter of 2014; one of them presented high volatility, and thus, a total of 65 companies were processed. Neither did we find a structural break in the average number of representative ratiosof companies with positive net equity (second line of results in table 4), indicating that the existence of unsecured liabilities at any moment of the series also in the debt ratio did not influence the path of the averages of Financial Dependency Ratios.

Table 4 - Financial Dependency Ratio - Structural Break in the Temporal Behavior

\begin{tabular}{|c|c|c|c|c|c|c|c|c|c|c|c|c|c|}
\hline $\mathbf{R}^{2}$ & D & Sample & ST & $\operatorname{AR}(3)$ & MA(1) & MA(2) & MA(3) & SMA(4) & ST & $\mathbf{A S}(2)$ & $\mathbf{A S}(5)$ & $\begin{array}{c}\text { CHOW } \\
2008\end{array}$ & $\begin{array}{c}\text { CHOW } \\
2010\end{array}$ \\
\hline \multirow[t]{2}{*}{0.53} & 0 & 1996Q4 & $\mathrm{COEF}$ & 0.39 & 0.39 & & & 0.96 & $\mathrm{~F}$ & 0.91 & 0.95 & 0.98 & 0.8 \\
\hline & & 2015Q1 & PROB & $0 * * *$ & $0 * * *$ & & & $0 * * *$ & $\mathrm{X}^{2}$ & 0.90 & 0.95 & 0.87 & 0.58 \\
\hline \multirow[t]{2}{*}{0.59} & 0 & 1996Q4 & $\mathrm{COEF}$ & & 0.86 & 0.86 & 0.98 & & F & 0.16 & 0.26 & 1 & 1 \\
\hline & & 2015Q1 & PROB & & $0 * * *$ & $0 * * *$ & $0 * * *$ & & $\mathrm{X}^{2}$ & 0.14 & 0.22 & 1 & 0.99 \\
\hline
\end{tabular}

where: *** Significant at the $1 \%$ level; D: Number of differentiations of the model; ST: Statistics; F: F Test; $\mathrm{x}^{2}$ : Chi-square test; C: intercept; AR: Autoregressive term; MA: Moving Average term; SAR: Autoregressive Seasonality term; SMA: Moving Average term; AS (2): Serial autocorrelation with two lags; AS (5): Serial autocorrelation with five lags; Chow2008: Structural Break in the fourth quarter of 2008; Chow2010: Structural Break in the fourth quarter of 2010; The second modeling also includes a constant with coefficient 0.92, an $\mathrm{AR}(1)$ term with coefficient -0.35 , and SAR (4) term with coefficient 0.40 all significant at the $1 \%$ level.

The sectorial analysis, based on a sample of 61 companies, since two observations were excluded due to them adding high volatility to the behavior of the Construction and Transportation sector. In this test, we only find evidence of structural breaks in the ratios of Financial Dependency of the Technology and Telecommunication sector; however, the test is limited to the average of only 3 companies.

Two arguments can be raised to explain the temporal behavior of this ratio; methodological - that would indicate regression impropriety of time series for aggregate data, since variations in the opposite direction can be absorbed by the adoption of the central tendency measure - and the conceptual, since the denominator and numerator of the ratio, in this case, tend to move in the same direction.

After the observation made above, we can reject the hypothesis of changes in the representation of financial dependency due to the Brazilian accounting standards change, after adding controls through the effect of macroeconomic variables on the economic situation of the sampled companies. 
Our findings on the Financial Dependency ratio differ from those mentioned by Martins and Paulo (2010). However, findings by Barbosa Neto, Dia and Pinheiro (2009) and by Dani, Vesco and Bezerra (2012) on the same ratio corroborate the present study. Such divergence may be justified due to the lower number of companies analyzed by the authors and the method used.

It is worth highlighting that comparisons on previous research mentioned here require caution in their understanding, since they all employ econometric methods and coefficient estimation techniques which may have consistency and efficiency (correlation and chi-square test, for example) different from those used here; and we can also mention the various sample sizes.

\section{CONCLUSIONS}

The findings indicated structural breaks statistically significant in the temporal behavior of the long-term Debt ratio (represented by the ratio between debt and net equity), with predominance in order to increase the leverage situation, leading to not rejecting the hypothesis established.

We do not investigate, through the hypothesis put forth, whether the change in the accounting standard in an economy changes the accounting representation of corporate debt, debt in itself, and so it is that we controlled the tests with macroeconomic variables, with the premise that the decision to borrow is associated with such conditions. Thus, it is worth mentioning the accounting's informational influence when adopting a particular way of reporting economic events in the company.

The same hypothesis, when being tested by the Financial Dependency ratio, that relates Debts with Total Assets, was rejected, despite applying the same macroeconomic control variables; however, we performed this test to all sets of sampled companies, as a central tendency measure, which may have influenced the results, but that leads to the inference that the accounting standard changes have idiosyncratic character to businesses and does not work unrestrictedly. Such subject deserves more detailed development in future research, which is already suggested here. At any rate, for users of accounting information that employ it for forecasts, it is worth cautioning that estimates based on accounting information require adjustments due to changes in its form of registration, be it generic as the implementation of new accounting standard, or specific to any accounting aggregate. In this sense, using the time series methodology in research and in practicing accounting analysis may produce benign effects to eliminate or mitigate errors due to the accounting treatment of financial and 
economic information. On the other hand, by jointly analyzing the structural breaks verified in the Debt ratio, it infers that the IFRS standard changed relevantly the information on companies leverage, and may thus alter the decision based on such accounting information.

In the present case, the change in the accounting treatment of financial leasing, as defined by the CPC 06- Leasing Operations, emerges almost spontaneously so to justify the change of the ratio behavior, given that its acknowledgment occurs in Liabilities (ratio numerator) and does not affect Net Equity (its denominator). However, the perception of its magnitude and of other influences is not so clear. That said, we understand that these findings may provide a basis for analytical and qualitative research, which indicates more effectively that standard changes would imply representation changes of economic and financial situations of companies based on their accounting representation.

The situation in which the structural break indicated a decrease in the level of debt could, on the other hand, be explained by the application of measurement of contracts' fair value, both in the form of cash and in the form of fixed assets recommended by CPC 11Insurance Contracts and CPC 27-Fixed Assets; or the effect of changes in accounting for investment properties (land) in construction companies, established by CPC 28-Investment Property in the evaluations of Assets and Net Equity.

The inferences of the research identified transformations derived from the implementation of the new Brazilian accounting standards, in long-term perspective and with the use of robust econometric technique. However, these are not sufficient regarding inferences about specific factors or causes that led to such changes.

Specifically on the adoption of international standard having provided changes in behavior of the debt ratio, the research is justified, because it brings evidence, in a statistically robust manner, of informational changes to be considered by users. If such a change is based on better quality of the IFRS standard, which focuses, conceptually, in the substance over form, transparency and the reliability of reported data, the scope of this research cannot provide a conclusion. There is evidence of a change in informational attributes for users of accounting information; thus, we recommend future research to attempt to measure the costbenefit ratio of such change here shown.

The contribution of the research to the literature rests on the evidence grounded on longterm informational disruption in the overall adoption of IFRS, although support for the informational benefit still requires targeted tests for that purpose. Furthermore, the application 
of the method - innovative in the field of accounting - with time series controlled by economic factors enable the separation of accounting informational effects from the effects of the facts acknowledged by accounting. The use of such a technique evaluating estimates of variables that have suffered some temporal cutting may be applied to examine and validate the quality of analysts' projections, both for the market as internally for companies. We suggest, in this regard, future studies using non-linear models (NARMAX-Nonlinear autoregressive integrated moving average model with exogenous factors) to model nonstationary time series whose modeling is limited by such characteristics of accounting data.

\section{CONTRIBUTIONS BY THE AUTHORS}

The article is the result of research developed as a requirement for completion of the MPhil in Business Administration and Controllership at the Federal University of Ceará from the author André Aroldo Freitas de Moura under the guidance of Prof. Antonio Carlos Coelho. The author André Aroldo Freitas de Moura proposed the methodological model, and developed the analysis and conclusions of the article. Professor Antonio Carlos Coelho improved the existing theoretical model, and guided all the work, as well as helped in article writing, which covered interpretations and conclusions of the results.

\section{REFERENCES}

AGGARWAL, R.; KLAPPER, L.; WYSOCKI, P. Portfolio preferences of foreign institutional investors. Journal of Banking and Finance, v. 29, p. 2919-2946, 2005.

ALFORD, A. et al. The relative informativeness of accounting disclosures in different countries. Journal of Accounting Research, v. 31, Supplement, p. 183-223, 1993.

ALI, A.; HWANG, L.-S. Country-specific factors related to financial reporting and the value relevance of accounting data. Journal of Accounting Research, v. 38, n.1, p. 1-21. 2000.

ASSAF NETO, A. Estrutura e análise de balanços: um enfoque econômico-financeiro. 9. ed. São Paulo: Atlas, 2010.

BARBOSA NETO, J. E.; DIAS, W. O.; PINHEIRO, L. E. T. Impacto da convergência para as IFRS na análise financeira: um estudo em empresas brasileiras de capital aberto. Revista Contabilidade Vista \& Revista, Belo Horizonte, v. 20, n. 4, p. 131-153, 2009.

BARTH, M. E.; LANDSMAN, W. R.; LANG, M. H. International accounting standards and accounting quality. Journal of Accounting Research, v. 46, p. 467-498, 2008.

BEUREN, I. M.; HEIN, N.; KLANN, R. C. Impact of the IFRS and US-GAAP on economicfinancial indicators. Managerial Auditing Journal, v. 23, n. 7, p. 632 - 649, 2008.

BOX, G. E. P.; JENKINS, G. M. Time series analysis: forecasting and control. San Francisco: Holden Day, 1976. 
BRASIL. Lei $\mathbf{n}^{0}$ 6.404, de 15 de dezembro de 1976. Dispõe sobre as Sociedades por Ações. Disponível em: <www.planalto.gov.br>. Acesso em: 15 jul. 2012.

Lei $\mathbf{n}^{\circ}$ 11.638, de 28 de dezembro de 2007. Altera e revoga dispositivos da Lei nº.404/76, e dá outras providências. Disponível em: <www.planalto.gov.br>. Acesso em: 15 jul. 2012.

Lei no 11.941 de 27 de maio de 2009. Conversão da Medida Provisória no 449 de 03/12/2008 (MP 449/08) em Lei. Disponível em<www.planalto.gov.br>. Acesso em: 15 jul. 2012.

BROWN, P.; PREIATO, J.; TARCA A. Measuring country differences in enforcement of accounting standards: an audit and enforcement proxy. Journal of Business Finance \& Accounting, v.41, n.1, p.1-52, 2014.

CALIXTO, L. Análise das pesquisas com foco nos impactos da adoção do IFRS em países europeus. Revista Contabilidade Vista \& Revista, Belo Horizonte, v. 21, n. 1, p. 157-187, jan./mar. 2010.

CALLAO, S.; JARNE, J. I.; LAÍNEZ, J. A. Adoption of IFRS in Spain: effect on the comparability and relevance of financial reporting. Journal of Accounting, Auditing and Taxation, v. 16, n. 2, p. 148-178, 2007.

CARVALHO, L. N.; LEMES, S. Padrões contábeis internacionais do IASB: um estudo comparativo com as normas contábeis brasileiras e sua aplicação. UnB Contábil, Brasília, v. 6, n.2, p.61-89, 2002.

CARVALHO, F. A. et al. Impactos de alterações nas práticas contábeis nos indicadores financeiros das empresas brasileiras. In: CONGRESSO USP DE CONTROLADORIA E CONTABILIDADE, São Paulo. Anais... São Paulo: 2011.

CHOI, F. D.; FROST, C. A.; MEEK, G. K. International accounting. 3. ed. USA: Pearson Education, 1999.

CHOW, G. C. Tests of equality between sets of coefficients in two linear regressions. Econometrica, v. 28, n. 3,p. 591-605, 1960.

COELHO, A. C., LIMA, I. S. Conservadorismo condicional: requisito para a qualidade dos lucros e para a eficiência informacional da contabilidade. REAd - Revista Eletrônica de Administração, v.15, p.5, 2009.

CORDAZZO, M. The impact of IAS/IFRS on accounting practices: evidences from Italian listed companies. In: Accounting Research Seminar Series, 2008. Disponível em: $<$ http://www.hec.unil.ch/urccf/seminar/Michela\%20Cordazzo\%20-\%20Dec07.pdf >. Acesso em: 15 jul. 2012.

COSTA, J. P. O impacto da adopção das IAS/IFRS nas demonstrações financeiras das empresas cotadas na Euronext Lisboa. 115f. Dissertação (Mestrado em Economia) Universidade do Porto, Portugal, Lisboa, 2008. 
DANI, A. C.; VESCO, D. G. D.; BEZERRA, F. A. Possíveis impactos da lei 11.638/2007 nos indicadores de desempenho das indústrias de real estate no Brasil. Revista Ciências sociais em Perspectiva, v.11, 2012.

ERNST \& YOUNG TERCO. IFRS $\mathbf{1}^{\circ}$ ano: análises sobre a adoção inicial no Brasil. Ernst \& Young Terco, 2011.

FLEURIET, M.; KEHDY, R.; BLANC, G. O modelo Fleuriet: a dinâmica financeira das empresas brasileiras. 3. ed. Rio de Janeiro: Campus, 2003.

GALLON, A. V. et al. As mudanças no tratamento contábil do leasing e seus reflexos nos indicadores econômico-financeiros das companhias aéreas brasileiras. Revista de Finanças Aplicadas, v. 1, p.1-18, 2012.

GOODWIN, J.; AHMED, K.; HEANEY, R. The effects of International Financial Reporting Standards on the accounts and accounting quality of Australian firms: a retrospective study. Journal of Contemporary Accounting and Economics, v. 4, n. 2, p. 89-119, 2008.

HAIL, L.; LEUZ, C.; WYSOCKI, P. Global accounting convergence and the potential adoption of IFRS by the United States: an analysis of economic and policy factors. Working Paper, 2009. Disponível em: http://ssrn.com/abstract=1357331. Acesso em: 05 maio 2013.

HUNG, M.; SUBRAMANYAM, K. R. Financial statement effects of adopting international accounting standards: the case of Germany. Review of Accounting Studies, v. 12, n. 4, p. 623-657, 2007.

LANTTO, A.-M.; SAHLSTRÖM, P. Impact of International Financial Reporting Standards adoption on key financial ratios. Accounting and Finance, v. 49, p. 341-361, 2009.

LEUZ, C.; TRIANTIS, A.; WANG, T. Why do firms go dark? causes and economic consequences of voluntary SEC deregistration. Journal of Accounting and Economics, v. 45, p. 181- 208, 2008.

LEMES, S.; CARVALHO, L. N. G. Comparabilidade entre o resultado em BR GAAP e U.S. GAAP: evidências das companhias brasileiras listadas nas bolsas norte-americanas. Revista Contabilidade \& Finanças, São Paulo, v. 20, n. 50, p. 25-45, mai./ago. 2009.

LEMES, S.; SILVA, M. G. A experiência de empresas brasileiras na adoção das IFRS. Revista Contabilidade Vista \& Revista, Belo Horizonte, v. 18, n. 3, p. 37-58, jul./set. 2007.

LIMA, J. B. N. A relevância da informação contábil e o processo de convergência para as normas IFRS no Brasil. 236p. Tese (Doutorado em Contabilidade e Controladoria) Faculdade de Economia, Administração e Contabilidade, Universidade de São Paulo, São Paulo, 2010.

LIMA, V. S. Incentivos no nível da firma e consequências econômicas da convergência ao IFRS no Brasil.172p. Dissertação (Mestrado em Ciências Contábeis) - Universidade de São Paulo (USP), São Paulo (SP), 2011. 
LUEG, R.; PUNDA, P.; BUKERT, M. Does transition to IFRS substantially affect key financial ratios in shareholder-oriented common law regimes? Evidence from the UK. Advances in Accounting, incorporating Advances in International Accounting, v.30, p.241-250, 2014.

MARIA JÚNIOR, E. et al. A interferência do padrão IFRS nos índices econômico financeiros das empresas listadas na BM\&Fbovespa. In: CONGRESSO USP DE CONTROLADORIA E CONTABILIDADE, São Paulo. Anais... São Paulo: 2012.

MARTINS, O. S.; PAULO, E. O reflexo da adoção das IFRS na análise de desempenho das companhias de capital aberto no Brasil. Revista de Contabilidade e Organizações - FEARP/USP, v. 4, n. 9, p. 30-54, maio-ago. 2010.

PEREIRA, V. S. et al. Análise comparativa entre as normas contábeis nacionais e internacionais em relação à forma de tratamento do cálculo do resultado de Equivalência Patrimonial. Revista de Gestão USP, São Paulo, v. 13, n. Especial, p. 45-62, 2006.

RIBEIRO, R. B. et al. Impactos da Adoção das IFRS nas Empresas Brasileiras Pertencentes ao índice Brasil: uma aplicação dos métodos de Kruskall - Wallis e cluster analysis. In: SEMINÁRIOS EM ADMINISTRAÇÃO (SEMEAD), 15., 2012, São Paulo. Anais... São Paulo: SEMEAD, 2012.

SANTOS, E. S.; CALIXTO, L. Impactos do início da harmonização contábil internacional (lei 11.638/07) nos resultados das empresas abertas. Revista de Administração Eletrônica (RAE), v.9, n.1, 2010.

SANTOS, E. S; PONTE, V. M. R; MAPURUNGA, P. V. R. Mandatory IFRS adoption in Brazil (2010): index of compliance with disclosure requirements and some explanatory factors of firms reporting. Revista Contabilidade e Finanças, v. 25, n.65, 2014.

SCHIPPER, K.; VINCENT, L. Earnings quality. Accounting Horizons, Sarasota, v. 17, supplement, p. 97-110, 2003.

SCHWARZ, G. E. Estimating the dimension of a model. Annals of Statistics, v. 6, n. 2, p. 461-464, 1978.

SILVA, B. A. O. ET AL. Comparabilidade dos indicadores econômico-financeiros das demonstrações financeiras em BRGAAP e IFRS. In: Simpósio de Excelência em Gestão e Tecnologia (SEGET), 8., 2011, Resende (RJ). Anais... Resende: SEGET, 2011.

SILVA, F. J. F.; COUTO, G. M. M.; CORDEIRO, R. M. O impacto das International Financial Reporting Standards (IFRS) na informação financeira de empresas portuguesas. Revista Universo Contábil, Blumenal, v. 5, n. 1, p. 129-144, jan./mar. 2009.

SILVA, R. L. M. Adoção completa das IFRS no Brasil: qualidade das demonstrações contábeis e o custo de capital próprio. 219 p. Tese (Doutorado em Contabilidade e Controladoria) - Faculdade de Economia, Administração e Contabilidade, Universidade de São Paulo (FEA-USP), São Paulo (SP), 2013.

SILVA, T. M.; NAKAO, S. H. Divulgação na adoção pela primeira vez de IFRS por empresas europeias de setores e sistemas jurídicos diferentes. Revista Contabilidade Vista \& Revista, Belo Horizonte, v. 22, n. 2, p. 93-124, abr./jun. 2011. 
STENT, W.; BRADBURY, M.; HOOKS, J. IFRS in New Zealand: effects on financial statements and ratios. Pacific Accounting Review, v. 22, n.2, p. 92 - 107, 2010.

TSALAVOUTAS, I.; EVANS, L. Transition to IFRS in Greece: financial statement effects and auditor size. Managerial Auditing Journal, v. 25, n. 8, p. 814 - 842, 2010.

YIP, R. W. Y.; YOUNG, D. Does mandatory IFRS adoption improve information comparability? The Accounting Review, v.87, n .5, p17-67, set. 2012. 